\title{
B Cell Proliferation
}

National Cancer Institute

\section{Source}

National Cancer Institute. B Cell Proliferation. NCI Thesaurus. Code C19385.

Growth and reproduction of B-lymphocytes. 